\title{
Correction to: Role of Total Thyroidectomy in Painful (Symptomatic) Hashimoto's Thyroiditis: Descriptive Study
}

\author{
Atul Mukul Bage ${ }^{1} \cdot$ Pradheep Kalatharan $^{1}$
}

Published online: 26 December 2020

(C) Association of Otolaryngologists of India 2020

\section{Correction to: Indian J Otolaryngol Head Neck Surg https://doi.org/10.1007/s12070-020-02114-2}

The article [Role of Total Thyroidectomy in Painful (Symptomatic) Hashimoto's Thyroiditis: Descriptive Study], written by [Atul Mukul Bage and Pradheep Kalatharan], was originally published online on [07 September 2020] with Open Access under a [This article is licensed under a Creative Commons Attribution 4.0 International License, which permits use, sharing, adaptation, distribution and reproduction in any medium or format, as long as you give appropriate credit to the original author(s) and the source, provide a link to the Creative Commons licence, and indicate if changes were made. The images or other third party material in this article are included in the article's Creative Commons licence, unless indicated otherwise in a credit line to the material. If material is not included in the article's Creative Commons licence and your intended use is not permitted by statutory regulation or exceeds the permitted use, you will need to obtain permission directly from the copyright holder. To view a copy of this licence, visit http://creativecommons. org/licenses/by/4.0/].

With the authors' decision to cancel Open Access the copyright of the article changed on [14 September 2020 provided by the OR Support team] to (C) Association of Otolaryngologists of India 2020 with all rights reserved.

Publisher's Note Springer Nature remains neutral with regard to jurisdictional claims in published maps and institutional affiliations.

The original article can be found online at https://doi.org/10.1007/s12070-020-02114-2.

Pradheep Kalatharan dr.pradheep88@gmail.com

1 Department of ENT, Sri Manakula Vinayagar Medical College and Hospital, Pondicherry, India 